\title{
Overview of Eyelid Tumors
}

\author{
Usha Singh and Raghavendra Rao Kolavali
}

\section{Overview and Epidemiology}

Eyelid is a common place for skin cancer to occur and constitute $5-10 \%$ of all skin cancers. Eyelid neoplasms comprise a variety of benign and malignant growths (Table 1.1). Significant majority of these growths are benign in nature and constitute $82-98 \%$ of all neoplasms (Table 1.2). There is wide, racial, and probable geographical variation reported in the incidence of the various eyelid tumors. Eyelid malignancies vary in distribution and presentation. The most common malignant eyelid tumor in western literature is basal cell carcinoma (BCC) comprising 86-91\% incidence among the Caucasians [7, 12]. However, in one of the largest series from China and India this incidence is much lower, consequently sebaceous gland carcinoma (SGC) constitutes $32 \%$ of all eyelid tumors [6, 13]. In studies from Asian countries [2, 14, 15] it is the sebaceous gland carcinoma which constitutes the majority $(67-77 \%)$. The mean age for benign tumor is lower than that of malignant tumors.

\footnotetext{
U. Singh $(\bowtie)$

Department of Ophthalmology, Advanced Eye Center, Post Graduate Institute of Medical Education and Research, Chandigarh, India
}

\section{R. R. Kolavali}

Department of Ophthalmology, Post Graduate Institute of Medical Education and Research, Chandigarh, India
Epithelial tumor and dermoid cysts are the most common eyelid tumor in children [16]. Malignant eyelid tumor in children is extremely rare. When it presents, is usually a part of a systemic process, genetic defects or following radiation treatment $[17,18]$. Merkel cell carcinomas (MCC) of the eyelid are rare neuroendocrine tumor constituting 5-20\% of the head and neck tumor, predominantly in Caucasians [19].

\section{Classification of Eyelid Tumors}

Eyelid tumors can arise from various histological layers eyelid is composed of. Eyelid tumors are classified as benign or malignant or according to the tissue or cell of origin (Tables 1.2, 1.3 and 1.4). They can be subdivided into non-melanocytic and melanocytic tumors. Benign epithelial proliferations such as squamous papilloma, pseudoepitheliomatous hyperplasia, seborrheic keratosis, keratoacanthoma cysts and nevi are common. Among the malignant, BCC (Figs. 1.1 and 1.2) is the most common in Caucasians and SGC among the Asians (Fig. 1.3), followed by squamous cell carcinoma (SCC) and malignant melanoma (MM) (Figs. 1.4, 1.5, 1.6, 1.7 and 1.8). The large majority of BCC $(93 \%)$ was seen in $71 \%$ of females [2] SGC has predilection for the upper lid [20]. Merkel cell cancer has higher prevalence in men. Primary malignant melanomas of the eyelid skin are rare and account for $0.2-13 \%$ of all reported 


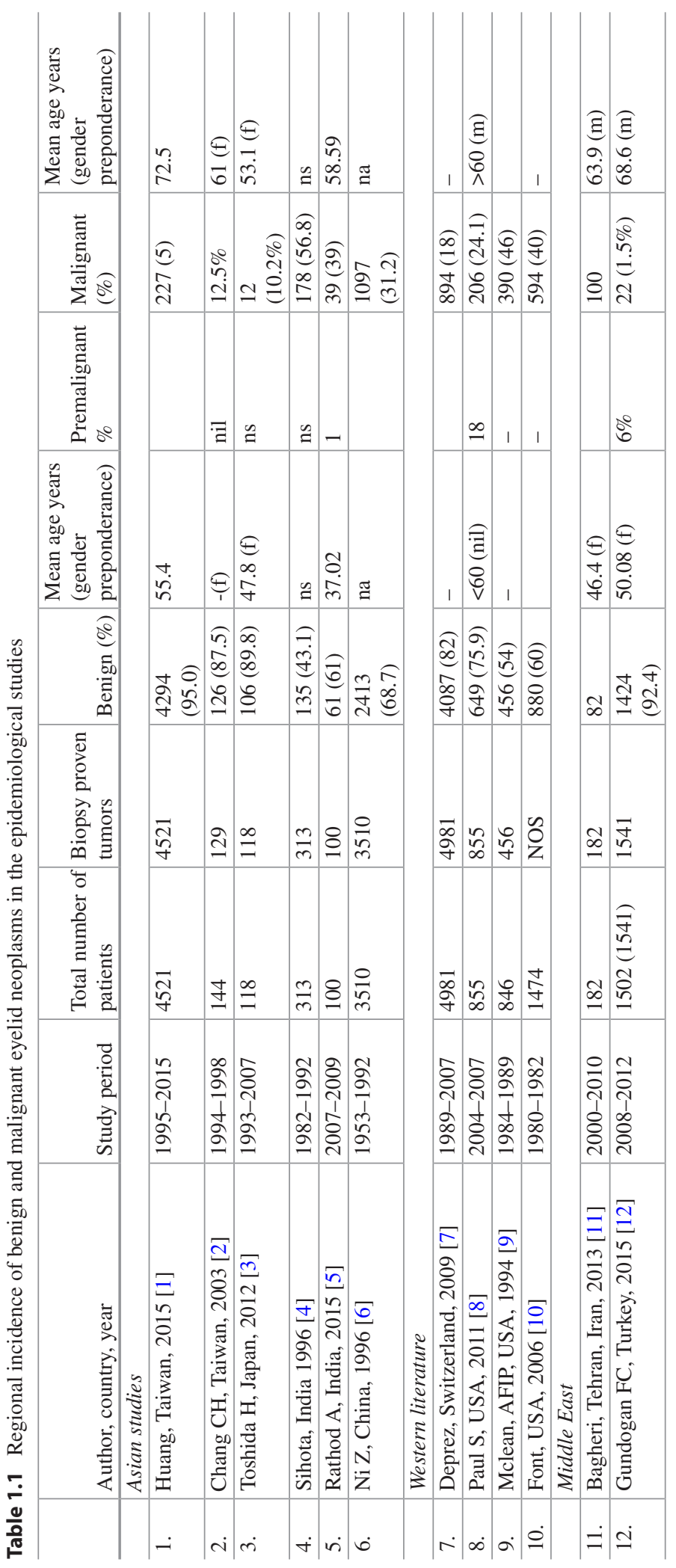


Table 1.2 Eyelid tumors originating from epidermis

\begin{tabular}{|c|c|c|c|}
\hline Subtypes & Benign & Premalignant & Malignant \\
\hline \multirow[t]{5}{*}{ Non-melanocytic } & Squamous cell papilloma & Actinic(solar) keratosis & Basal cell carcinoma \\
\hline & Seborrheic keratosis & Intraepithelial neoplasia & $\begin{array}{l}\text { Squamous cell } \\
\text { carcinoma }\end{array}$ \\
\hline & Inverted follicular keratosis & $\begin{array}{l}\text { Sebaceous nevus (of } \\
\text { Jadassohn) }\end{array}$ & $\begin{array}{l}\text { Mucoepidermoid } \\
\text { carcinoma }\end{array}$ \\
\hline & $\begin{array}{l}\text { Reactive hyperplasia } \\
\text { (pseudoepitheliomatous } \\
\text { hyperplasia) }\end{array}$ & Xeroderma pigmentosa & Keratoacanthoma \\
\hline & & Keratoacanthoma & \\
\hline \multirow[t]{11}{*}{ Melanocytic } & Ephelis or freckles & $\begin{array}{l}\text { Congenital dysplastic } \\
\text { nevus }\end{array}$ & \\
\hline & Lentigo simplex & \multirow[t]{10}{*}{$\begin{array}{l}\text { Lentigo maligna (melanotic } \\
\text { freckle of Hutchinson) }\end{array}$} & $\begin{array}{l}\text { Melanoma arising from } \\
\text { nevi }\end{array}$ \\
\hline & Solar Lentigo & & $\begin{array}{l}\text { Melanoma arising in } \\
\text { lentigo maligna }\end{array}$ \\
\hline & Junctional nevus & & \multirow{8}{*}{$\begin{array}{l}\text { Melanoma arising de } \\
\text { novo }\end{array}$} \\
\hline & Intradermal nevus & & \\
\hline & Compound nevus & & \\
\hline & Spitz nevus & & \\
\hline & Balloon cell nevus & & \\
\hline & Blue nevus & & \\
\hline & Cellular blue nevus & & \\
\hline & Oculodermal nevus of Ota & & \\
\hline \multicolumn{4}{|c|}{ Eyelid tumors arising from adnexal and cystic lesions } \\
\hline \multirow{2}{*}{$\begin{array}{l}\text { Sebaceous gland } \\
\text { tumors }\end{array}$} & Sebaceous gland hyperplasia & \multirow[t]{7}{*}{-} & Sebaceous gland \\
\hline & Sebaceous gland adenoma & & carcinoma \\
\hline \multirow{5}{*}{$\begin{array}{l}\text { Sweat gland and } \\
\text { lacrimal gland } \\
\text { tumors }\end{array}$} & Syringoma & & $\begin{array}{l}\text { Sweat gland (eccrine) } \\
\text { adenocarcinoma }\end{array}$ \\
\hline & Papillary syringadenoma & & $\begin{array}{l}\text { Mucinous sweat gland } \\
\text { adenocarcinoma }\end{array}$ \\
\hline & Eccrine spiradenoma & & $\begin{array}{l}\text { Apocrine gland } \\
\text { adenocarcinoma }\end{array}$ \\
\hline & Eccrine acrospiroma & & $\begin{array}{l}\text { Adenoid cystic } \\
\text { carcinoma }\end{array}$ \\
\hline & & & Porocarcinoma \\
\hline \multicolumn{4}{|c|}{ Eyelid tumors arising from hair follicle } \\
\hline & Trichoepithelioma & & \multirow{4}{*}{$\begin{array}{l}\text { Carcinoma of hair } \\
\text { follicles }\end{array}$} \\
\hline & Trichofolliculoma/trichoadenoma & & \\
\hline & Trichilemmoma & & \\
\hline & $\begin{array}{l}\text { Pilomatrixoma (calcifying } \\
\text { epithelioma of Malherbe) }\end{array}$ & & \\
\hline
\end{tabular}

Other cystic lesions

Epidermal inclusion cyst

Sebaceous cyst

Retention cyst

Eccrine hidrocystoma

Apocrine hidrocystoma

Trichilemmal cyst

Other benign cystic lesion 
Table 1.3 Fibrous, fibrohistiocystic, and muscular eyelid tumors

\begin{tabular}{|c|c|c|c|}
\hline & Benign & Intermediate & Malignant \\
\hline \multirow[t]{5}{*}{ Fibrous } & Fibroma & & \multirow{5}{*}{$\begin{array}{l}\text { Fibrosarcoma } \\
\text { Congenital fibrosarcoma }\end{array}$} \\
\hline & Keloid & & \\
\hline & Nodular fasciitis & & \\
\hline & Proliferative fasciitis & & \\
\hline & Fibromatosis & & \\
\hline \multirow{8}{*}{$\begin{array}{l}\text { Fibrous } \\
\text { histiocytic }\end{array}$} & Xanthelasma & & Malignant fibrous histiocytoma \\
\hline & Xanthoma & Atypical fibroxanthoma & $\begin{array}{l}\text { Malignant giant cell fibrous } \\
\text { histiocytoma }\end{array}$ \\
\hline & Dermatofibroma & $\begin{array}{l}\text { Dermatofibrosarcoma } \\
\text { protuberans }\end{array}$ & \multirow[t]{6}{*}{ Malignant fibroxanthoma } \\
\hline & Xanthogranuloma & \multirow{5}{*}{$\begin{array}{l}\text { Angiomatoid fibrous } \\
\text { histiocytoma }\end{array}$} & \\
\hline & Fibrous histiocytoma & & \\
\hline & $\begin{array}{l}\text { Juvenile } \\
\text { xanthogranuloma }\end{array}$ & & \\
\hline & $\begin{array}{l}\text { Necrotic } \\
\text { xanthogranuloma }\end{array}$ & & \\
\hline & Reticulohistiocytoma & & \\
\hline & & Benign & Malignant \\
\hline \multirow[t]{2}{*}{ Smooth muscle } & & Leiomyoma & \multirow[t]{2}{*}{ Leiomyosarcoma } \\
\hline & & Angiomyoma & \\
\hline Skeletal muscle & & Rhabdomyoma & Rhabdomyosarcoma \\
\hline
\end{tabular}

Table 1.4 Eyelid tumors arising from vascular, perivascular, neural, lipomatous, cartilage, bone lymphoid tumors, hamartomas, and choristomas

\begin{tabular}{|c|c|c|}
\hline & Benign & Malignant \\
\hline \multirow[t]{8}{*}{ Vascular } & Nevus flammeus (port wine stain) & Angiosarcoma \\
\hline & Papillary endothelial hyperplasia & Lymphangiosarcoma \\
\hline & Capillary hemangioma & \multirow[t]{6}{*}{ Kaposi’s sarcoma } \\
\hline & Cavernous hemangioma & \\
\hline & Venous hemangioma & \\
\hline & $\begin{array}{l}\text { Epithelioid hemangioma (angiolymphoid } \\
\text { hyperplasia) }\end{array}$ & \\
\hline & Arteriovenous malformation & \\
\hline & Lymphangioma & \\
\hline \multirow[t]{2}{*}{ Perivascular } & Hemangiopericytoma & Malignant hemangiopericytoma \\
\hline & Glomus tumor & Malignant glomus tumor \\
\hline \multirow[t]{5}{*}{ Neural } & Traumatic neuroma & $\begin{array}{l}\text { Malignant peripheral nerve sheath } \\
\text { tumor }\end{array}$ \\
\hline & Neurofibroma & \multirow[t]{4}{*}{ Merkel cell tumor } \\
\hline & Plexiform neurofibroma & \\
\hline & Schwannoma (neurilemoma) & \\
\hline & Neuroglial choristoma & \\
\hline \multirow[t]{2}{*}{ Lipomatous } & Lipoma & \multirow[t]{2}{*}{ Liposarcoma } \\
\hline & Hibernoma & \\
\hline \multirow[t]{3}{*}{ Cartilage } & Chondroma & Chondrosarcoma \\
\hline & \multirow[t]{2}{*}{ Osteoma } & Mesenchymal chondrosarcoma \\
\hline & & Osteosarcoma \\
\hline \multirow[t]{2}{*}{ Lymphoid } & Benign lymphoid hyperplasia & Lymphoma \\
\hline & Plasmacytoma & Leukemic infiltration \\
\hline \multirow{3}{*}{$\begin{array}{l}\text { Hamartomas and } \\
\text { choristomas }\end{array}$} & Dermoid cyst & \\
\hline & Phakomatous choristoma & \\
\hline & Ectopic lacrimal gland & \\
\hline Others & Myxoma & \\
\hline
\end{tabular}



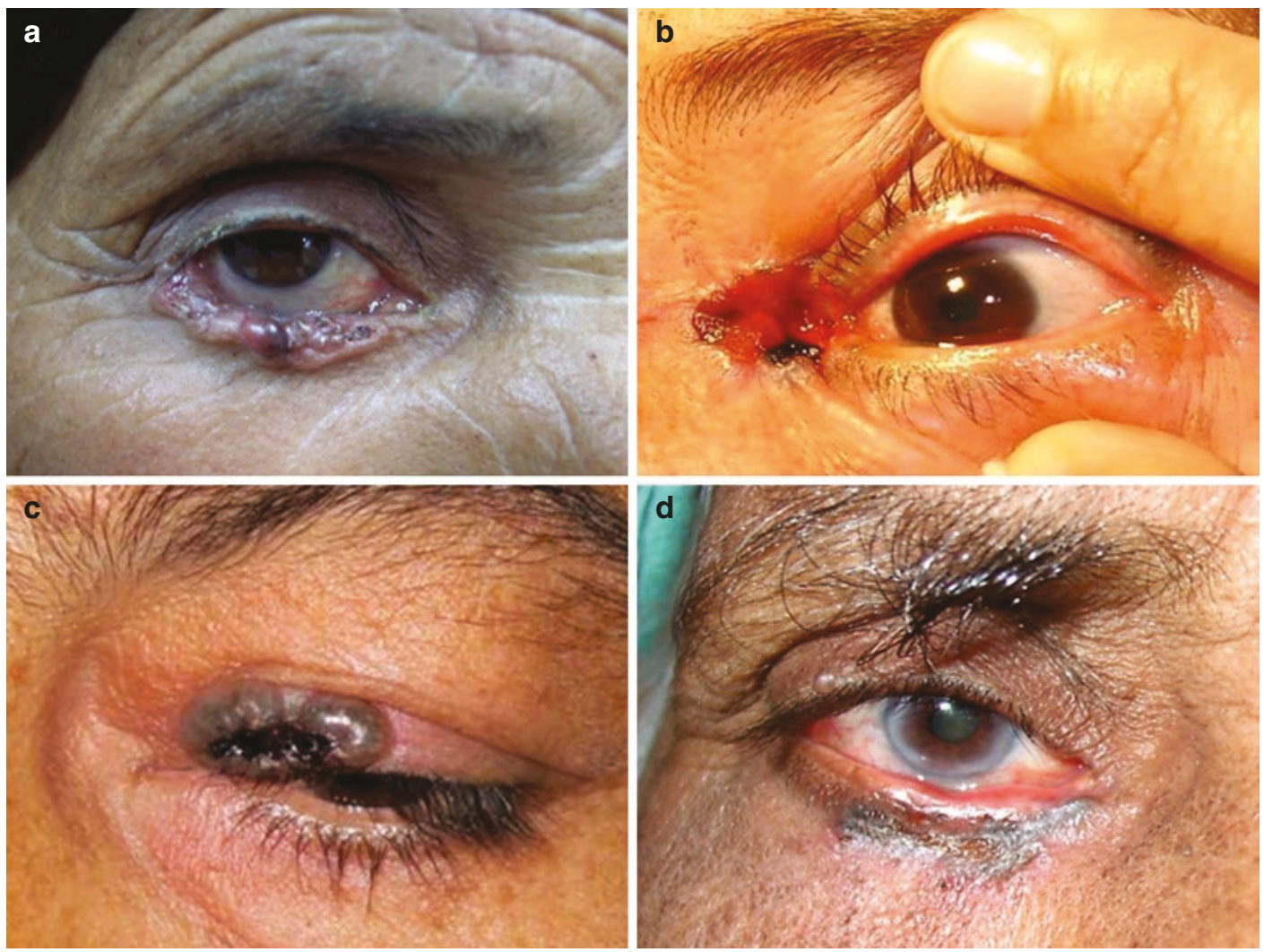

Fig. 1.1 (a) Basal cell carcinoma involving the lower lid. (b) Ulcerative basal cell carcinoma involving the medial canthus. (c) Basal cell carcinoma involving the upper lid

with central necrotic area. (d) Morpheaform type of basal cell carcinoma involving the lower lid

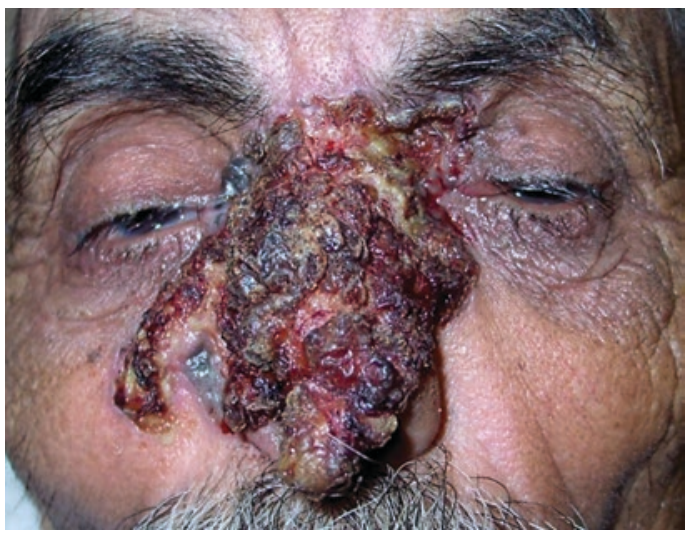

Fig. 1.2 Extensive basal cell carcinoma involving both medial canthi, nose and cheek

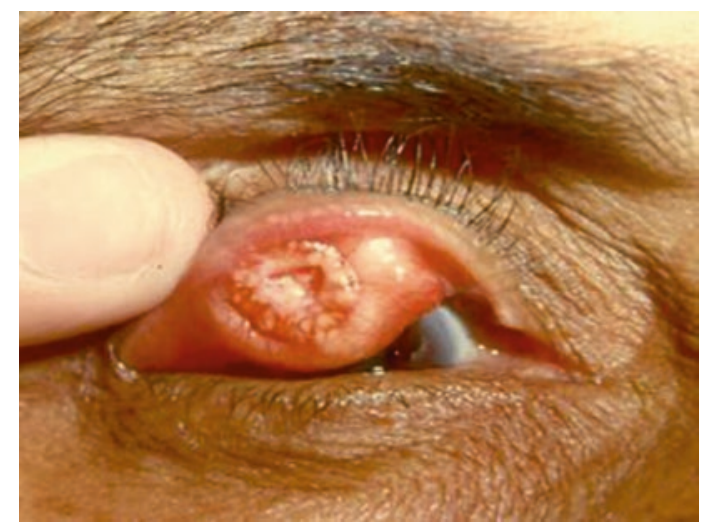

Fig. 1.3 Sebaceous gland carcinoma misdiagnosed as chalazion and surgically intervened 


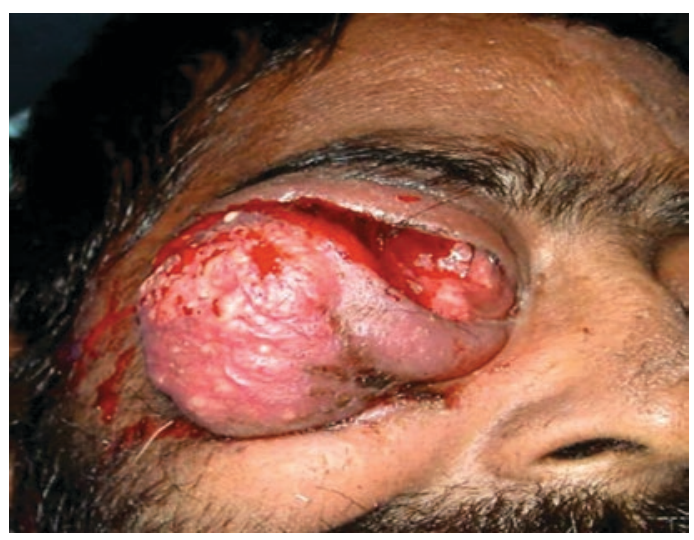

Fig. 1.4 Malignant melanoma involving lower lid and conjunctiva

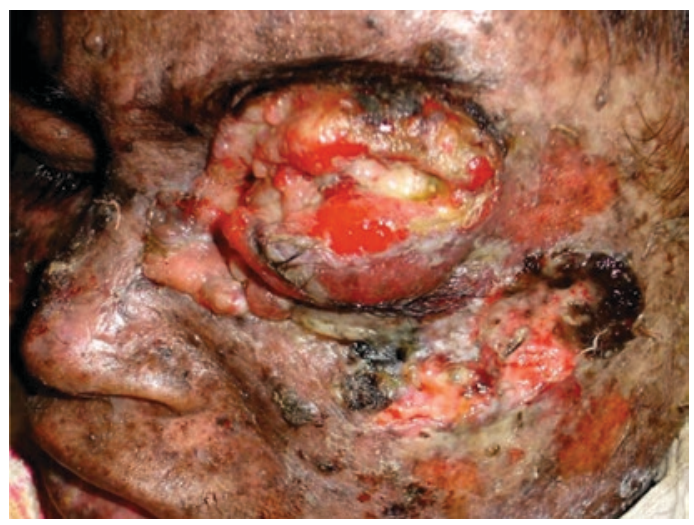

Fig. 1.5 Extensive malignant melanoma involving both the eyelids in a patient with xeroderma pigmentosa cases $[2,7]$. They occur 20 years later than other non-melanoma tumor and have 2.6 times predilection for the lower lid. Eyelids can also be involved by secondary and metastatic lesions.

All primary carcinomas of the eyelid can be classified based on their clinical and histological presentation using the TNM [tumor, nodes (lymph), metastasis] by AJCC (8th Ed) classification system [21]. TNM staging describes the size of tumor, number and location of regional lymph nodes which have malignant cells in them and whether the malignant cells have spread or metastasized to another part of the body. The TNM classification of eyelid carcinomas reflects both morbidity and mortality risks in order to provide useful guidelines for patient management.

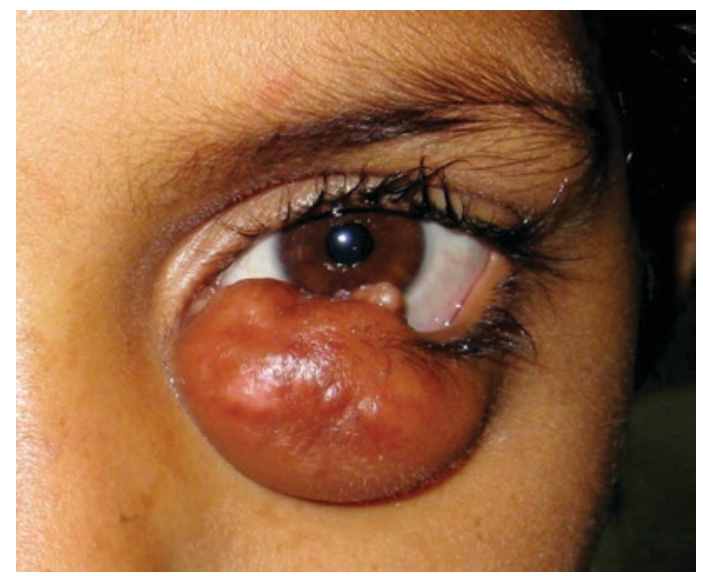

Fig. 1.6 Rapidly growing squamous cell carcinoma of the eyelid and extending to the orbit

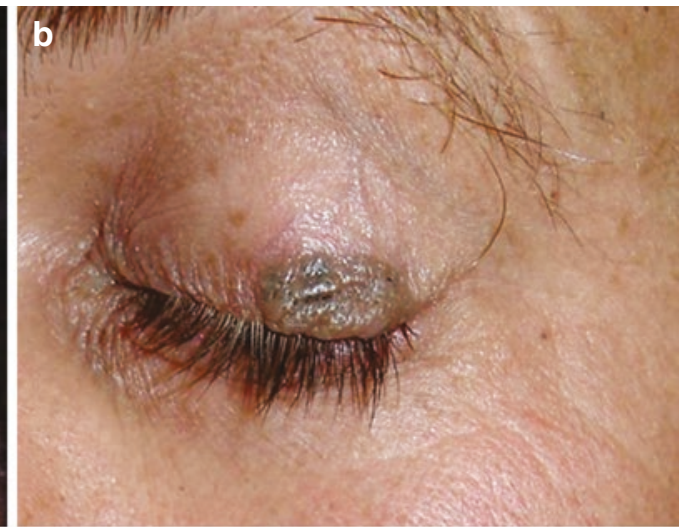

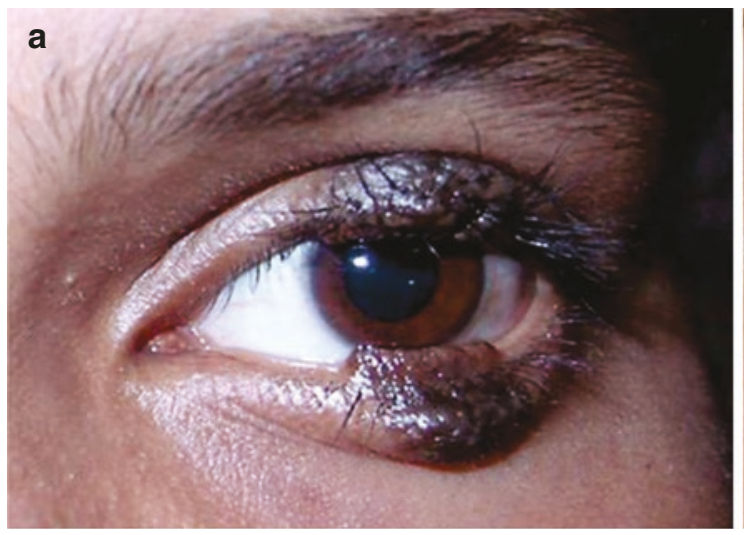

Fig. 1.7 (a) Kissing nevus in a young adolescent girl. (b) Nevi involving the upper lid in a young adult with a history of recent growth. (c) Nevus involving the lid margin in a young adult. (d) Keratoacanthoma 

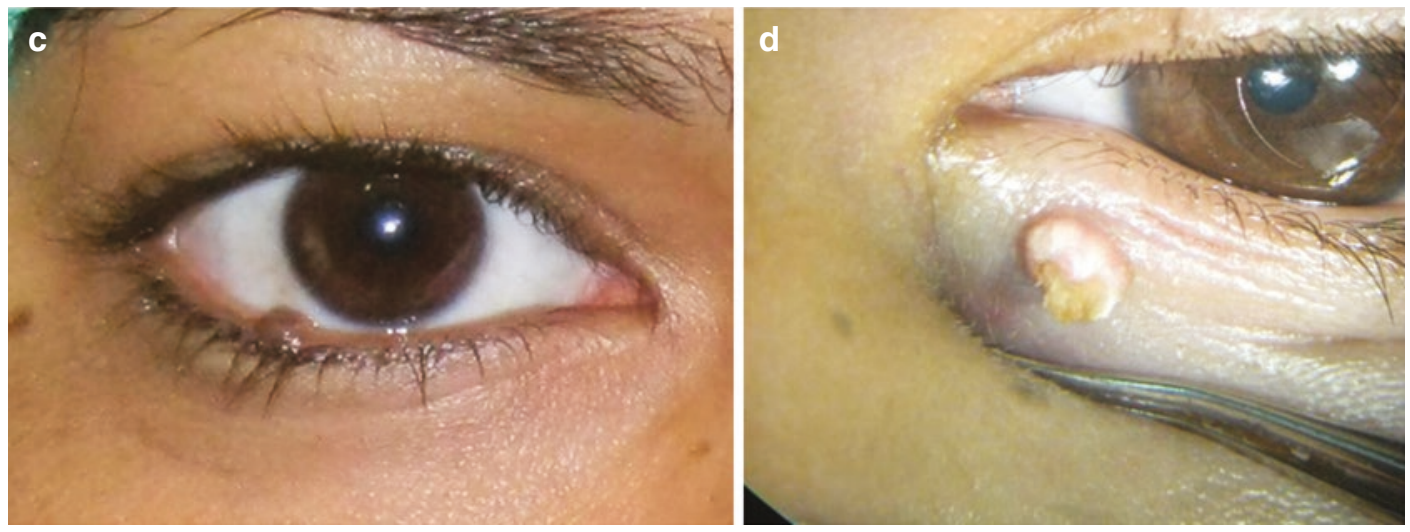

Fig. 1.7 (continued)
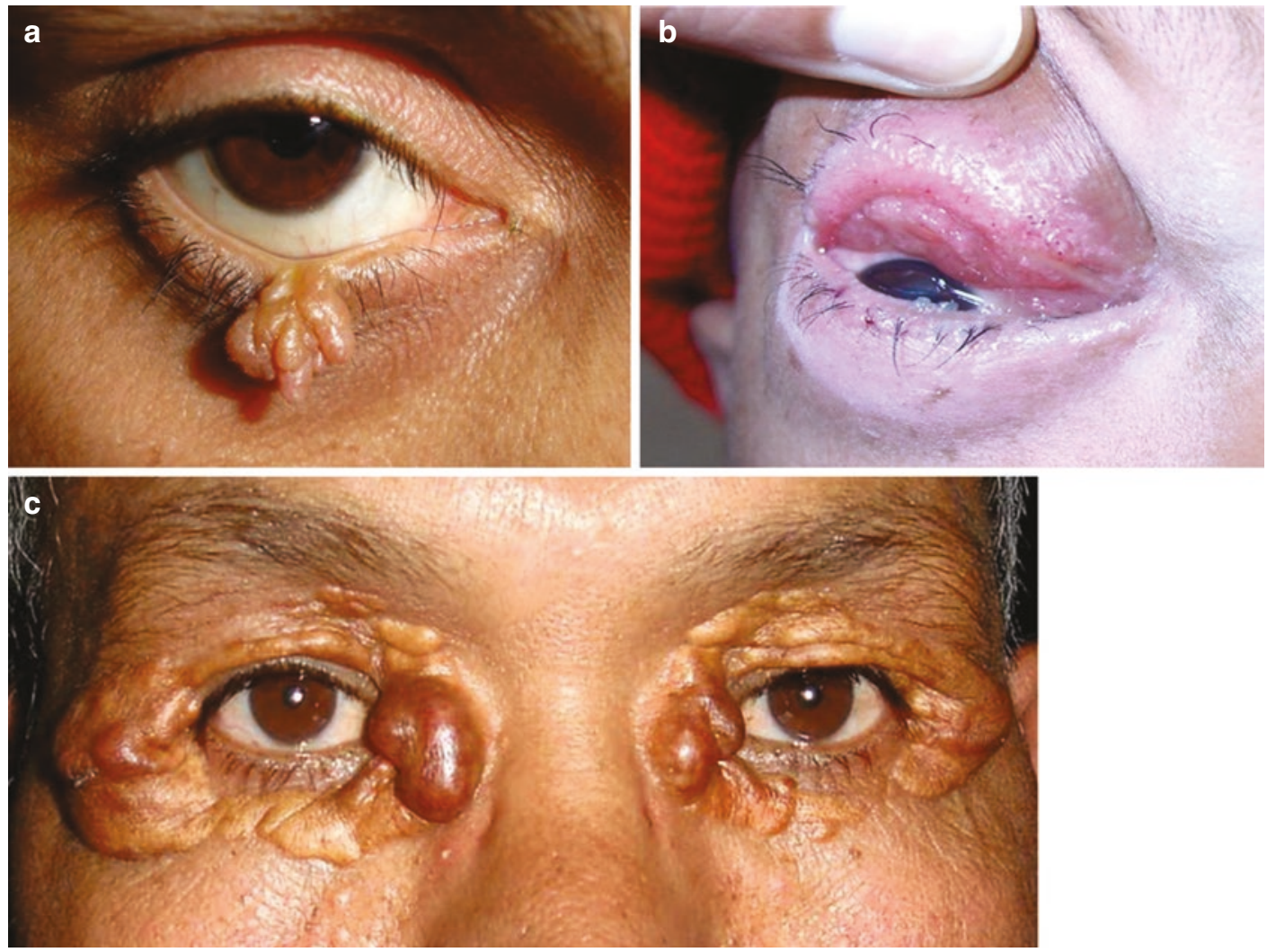

Fig. 1.8 (a) Squamous papilloma of the lower eyelid. (b) Lymphangioma diffusely involving the lids and orbit. (c) Extensive Xanthelesma involving all four lids 


\section{References}

1. Huang YY, Liang WY, Tsai CC, Kao SC, Yu WK, Kau $\mathrm{HC}$, et al. Comparison of the clinical characteristics and outcome of benign and malignant eyelid tumors: an analysis of 4521 eyelid tumors in a tertiary medical center. BioMed Res Int. 2015;5 pages:453091. https:// doi.org/10.1155/2015/453091.

2. Chang CH, Chang SM, Lai YH, Huang J, Su MY, Wang HZ, et al. Eyelid tumors in southern Taiwan: a 5-year survey from a medical university. Kaohsiung J Med Sci. 2003;19:549-54.

3. Toshida H, Mamada N, Fujimaki T, Funaki T, Ebihara $\mathrm{N}$, Murakami A, Okisaka S, et al. Incidence of benign and malignant eyelid tumors in Japan. Int $\mathrm{J}$ Ophthalmic Pathol. 2012;1(2):112-4.

4. Sihota R, Tandon K, Betharia SM, Arora R. Malignant eyelid tumors in an Indian population. Arch Ophthalmol. 1996;114(1):108-9.

5. Rathod A, Pandharpurkar M, Toopalli K, Bele S. A clinicopathological study of eyelid tumours and its management at a tertiary eye care center of southern India. MRIMS J Health Sci. 2015;3(1):54-8.

6. Ni Z. Histopathological classification of 3510 cases with eyelid tumor. Zhonghua Yan KeZaZhi. 1996;32:435-7.

7. Deprez M, Uffer S. Clinicopathological features of eyelid skin tumors. A retrospective study of 5504 cases and review of literature. Am J Dermatopathol. 2009;31(3):256-62.

8. Paul S, Vo DT, Silkiss RZ. Malignant and benign eyelid lesions in San Francisco: study of a diverse urban population. Am J Clin Med. 2011;8(1):40-6.

9. McLean IW, Burnier MN, Zimmerman LE, et al. Tumors of the eyelid. In: Tumors of the eye and ocular adnexa. Washington, DC: American Registry of Pathology/AFIP; 1994. p. 7-47.

10. Font RL, Croxatto JO, Rao NA. Tumors of the eyelids. In: Tumors of the eye and ocular adnexa. Washington, DC: American Registry of Pathology/AFIP; 2006. p. $155-22$.
11. Bagheri A, Tavakoli M, Kanaani A, Zavareh RB, Esfandiari H, Aletaha M, et al. Eyelid masses: a 10-year survey from a tertiary eye hospital in Tehran. Middle East Afr J Ophthalmol. 2013;20(3):187-92.

12. Gundogan FC, Yolcu U, Tas A, Sahin OF, Uzun S, Cermik H, et al. Eyelid tumors: clinical data from an eye Center in Ankara, Turkey. Asian Pac J Cancer Prev. 2015;16(10):4265-9.

13. Kale SM, Patil SB, Khare N, Math M, Jain A, Jaiswal S. Clinicopathological analysis of eyelid malignancies- a review of 85 cases. Indian J Plast Surg. 2012;45(1):22-8.

14. Prabha DP, Padmavathi P, Ather M. Clinicopathological study of malignant eyelid tumours. Sch J App Med Sci. 2015;3(6A):2165-8.

15. Ho M, Liu DTL, Chong KKL, Ng HK, Lam DSC. Eyelid tumours and pseudotumours in Hong Kong: a ten-year experience. Hong Kong Med J. 2013;19(2):150-5.

16. Hsu HC, Lin HF. Eyelid tumors in children: a clinicopathologic study of a 10 -year review in southern Taiwan. Ophthalmologica. 2004;218(4):274-7.

17. Al-Buloushi A, Filho JP, Cassie A, Arthurs B, Burnier MN Jr. Basal cell carcinoma of the eyelid in children: a report of three cases. Eye. 2005;19:1313-4. https:// doi.org/10.1038/sj.eye.6701758.

18. Nerad JA, Whitaker DC. Periocular basal cell carcinoma in adults 35 years of age and younger. Ophthalmology. 1988;106:723-9.

19. Lemos BD, Storer BE, Iyer JG, Phillips JL, Bichakjian CK, Fang LC, et al. Pathologic nodal evaluation improves prognostic accuracy in Merkel cell carcinoma: analysis of 5823 cases as the basis of the first consensus staging system. J Am Acad Dermatol. 2010;63(5):751-61.

20. Kaliki S, Ayyar A, Dave TV, Ali MJ, Mishra DK, Naik MN. Sebaceous gland carcinoma of the eyelid: clinicopathological features and outcome in Asian Indians. Eye. 2015;29:958-63.

21. The American Joint Committee on Cancer. In: Amin MB, et al., editors. AJCC cancer staging manual. 8th ed; 2017. p. 779-85. https://doi. org/10.1007/978-3-319-40618-3_64.

Open Access This chapter is licensed under the terms of the Creative Commons Attribution 4.0 International License (http://creativecommons.org/licenses/by/4.0/), which permits use, sharing, adaptation, distribution and reproduction in any medium or format, as long as you give appropriate credit to the original author(s) and the source, provide a link to the Creative Commons license and indicate if changes were made.

The images or other third party material in this chapter are included in the chapter's Creative Commons license, unless indicated otherwise in a credit line to the material. If material is not included in the chapter's Creative Commons license and your intended use is not permitted by statutory regulation or exceeds the permitted use, you will need to obtain permission directly from the copyright holder.

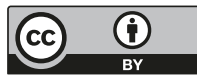

